\title{
Relationship between protein markers and the sensory/ physicochemical parameters of ovine meat during refrigerated storage
}

\author{
Isadora Martínez-Arellano ${ }^{(1)}$, Patricia Severiano-Pérez ${ }^{(2)}$, Francisco José Fernández ${ }^{(3)}$, \\ Héctor Escalona-Buendía (3), Edith Ponce-Alquicira ${ }^{(3)}$ \\ (1) Instituto de Ciencias Aplicadas y Tecnología, UNAM, Circuito Exterior s/n, Ciudad Universitaria, 04510 México City \\ (Mexico). \\ (2) Universidad Nacional Autónoma de México, Facultad de Química, Departamento de Alimentos y Biotecnología, Ciudad \\ Universitaria, CP 04510 , Mexico City (Mexico). \\ (3) Universidad Autonoma Metropolitana-Iztapalapa, Departamento de Biotecnología, Av. San Rafael Atlixco No. 186 , Col. \\ Vicentina, CP 09340, Mexico City (Mexico).E-mail: pae@xanum.uam.mx
}

Received 3 August 2017, accepted 4 May 2020, available online 8 June 2020.

This article is distributed under the terms and conditions of the CC-BY License (http://creativecommons.org/licenses/by/4.0)

Description of the subject. Commercialization requires the storage of meat for a period of time according to the distribution and supply chain, usually under refrigeration and vacuum packaging. During this stage, many biochemical reactions can modify the sensory and physicochemical properties of meat. Proteolysis is one of the most important of these reactions as proteins are the building blocks of muscle, and their degradation affects tenderness.

Objectives. The objectives of this study were to use multiple factorial analyses to correlate the physicochemical, sensory, and proteolytic changes in ovine meat during refrigeration.

Method. Each loin was separated and randomly assigned to day 3, 5, or 14. Sensory panel evaluated the meat for appearance, odor and texture parameters. Warner-Bratzler shear force and texture profile analysis were evaluated. Similarly, protease activity was evaluated. Samples for 2D-electrophoresis and western blotting were collected at days 3,5 , and 14 post mortem. The results were analyzed by multiple factorial analyses.

Results. The relative protein levels of desmin, vinculin, and myosin were found to decrease with time. Multiple factor analysis showed that the Warner-Bratzler shear force (WBSF) was highly correlated with the relative desmin concentration, the relative vinculin concentration, and acidic protease activity. The activities of acidic and neutral proteases were positively correlated with myosin level on day 3, but were negatively correlated with manual tenderness and myosin level on days 5 and 14 .

Conclusions. Therefore, desmin, myosin and vinculin, which correlate with sensory and physicochemical parameters during refrigerated storage, may prove useful as markers for tenderness.

Keywords. 2D electrophoresis, multiple factor analysis, western blot, organoleptic analysis.

Relation entre marqueurs protéiques et paramètres sensoriels et physico-chimiques de la viande ovine au cours de la réfrigération

Description du sujet. La commercialisation de la viande implique une période de stockage, en général sous réfrigération et en emballage sous vide. Au cours de cette étape, de nombreuses réactions biochimiques peuvent modifier les propriétés sensorielles et physico-chimiques de la viande.

Objectifs. Les objectifs de cette étude étaient d'utiliser une analyse multifactorielle pour corréler les changements physicochimiques, sensoriels et ceux liés à la protéolyse ayant lieu dans la viande ovine au cours de la réfrigération. Pendant le stockage, les quantités relatives des protéines desmine, vinculine et myosine ont diminué au cours du temps.

Méthode. Les muscles longissimus lumborum ont été prélevés $6 \mathrm{~h}$ post mortem. Une évaluation sensorielle et physico-chimique ainsi qu'une électrophorèse $2 \mathrm{D}$ et un western blot ont été réalisés. Les concentrations protéiques relatives et leur relation avec les paramètres physico-chimiques et sensoriels ont été analysés par analyse factorielle multiple.

Résultats. L'analyse multifactorielle a montré que la force de cisaillement de Warner-Bratzler était hautement corrélée à la concentration relative de desmine, à la concentration relative de vinculine et à l'activité protéasique acide. Les activités des 
protéases acides et neutres étaient positivement corrélées à la quantité de myosine au jour 3 , mais négativement corrélées à la tendreté manuelle et à la quantité de myosine aux jours 5 et 14 .

Conclusions. Par conséquent, la desmine, la myosine et la vinculine, corrélées aux paramètres sensoriels et physico-chimiques pendant la réfrigération, pourraient constituer des marqueurs pertinents de la texture de viande ovine.

Mots-clés. Électrophorèse 2D, analyse multifactorielle, western blot, analyse organoleptique.

\section{INTRODUCTION}

In recent years, ovine meat production has grown at about $0.8 \%$ annually in world (FAO, 2019). It is estimated that 15.301 million tons of meat will be consumed worldwide in 2020 and projections show a rise up to 17 million tons for 2028 (OECD, 2020). Among the different sources for meat production, the ovine production has added benefits since they can eat a variety of low-quality crops and are able to live in moderate to harsh environments.

A wide variety of physicochemical and sensory changes during the meat storage influences the final meat characteristics, such as appearance, odor and texture, which in turn affects their purchasing behavior. Meat storage, under refrigeration, reduces the shortening of meat as well as improves its odor and tenderness. This is due to the intensive degradation of the myofibrillar and sarcoplasmic proteins during the storage, which ultimately contributes to the quality of meat. Proteomics have great potential to enhance knowledge on the biochemical processes underlying the conversion of muscle into meat, by identifying biomarkers specific to meat quality, immediately after slaughter, which can be used to select the best quality carcasses (Pospiech et al., 2007).

The relationship between proteolysis and tenderness has been previously studied including degradation of desmin in pig biceps femoris muscle that explained $38 \%$ of the variation in sensory tenderness. However, the same behavior was not observed, using pig longissimus dorsi muscle (Wheeler et al., 2000). Moreover, Tomisaka et al. (2010) reported that the level of labeled desmin decreased by $51 \%$ in 12 to $96 \mathrm{~h}$ post mortem in chicken gizzard. Similarly, another study in bovine longissimus thoracis muscles observed desmin by products $76 \mathrm{~h}$ post mortem to day 56 of storage (Huff-Lonergan et al., 1996a). Likewise, Anderson et al. (2012) have identified potential markers, like myosin light chain-1, actin and myomesin-2, in muscles that differ in tenderness. Furthermore, Gagaoua et al. (2017) analyzed the relationship between protein biomarkers and meat quality in PDO Maine-Anjou bovines. They observed that myosin light chain played an important role in meat quality by regulating the activities of glycolytic enzymes. In addition, Kiran et al. (2016) identified proteins, namely uroplakin-1b, aspartate aminotransferase, myosin-IIIa, glycogen phosphorylase, cytosolic carboxypeptidase 3 and phosphatidylinositol transfer protein $\beta$ isoform, having positive correlation with tenderness in buffalo meat. Likewise, heat shock, metabolic, structural, oxidative resistant and proteolytic proteins were reported as potential biomarkers for tenderness in beef (Picard et al., 2014).

There are numerous reports regarding the proteomics of cattle, pork, poultry meat, but there are few proteomic studies on ovine meat. Although, sensory attributes have been studied in ovine (Revilla et al., 2009; Muela et al., 2012; Jandasek et al., 2014), there are few studies studying the relationship between the changes in proteins and physicochemical parameters occurring during storage (Starkey et al., 2016).

The objectives of the present study were to use multiple factorial analysis in an effort to correlate the physicochemical parameters, sensory parameters, and proteolytic changes in ovine meat during refrigerated storage. Likewise, the biomarkers were associated to sensory and physicochemical characteristics.

\section{MATERIALS AND METHODS}

\subsection{Animals and sampling}

Twenty-seven 1-year-old Pelibuey lambs were slaughtered in a commercial abattoir in Mexico City. The longissimus lumborum muscles were dissected after $6 \mathrm{~h}$ post mortem. One loin/animal was separated and randomly assigned to day 3, 5, or 14 .

The loins were vacuum packaged at -700 mbar in Cryovac LB-50 bags (Sealed Air de Mexico SRL CV, Mexico) using a Multivac vacuum (model D-8941; Koch, Kansas City, MO, USA) and stored at $2 \pm 1{ }^{\circ} \mathrm{C}$ for 14 days without light.

\subsection{Sensory evaluation}

The panel was recruited and selected from an initial group of 30 participants ( 22 women, 8 men) ranging from 20 to 26 years old. The process included a questionnaire about eating habits, age, allergies and availability. The selection was based on the volunteers' ability to differentiate basic tastes, their discriminative ability (ASTM, 1981) and olfactory capacity (Severiano-Pérez et al., 2012). Participants that presented a threshold equal to or lower than that of the whole group were chosen. In addition, participants 
who obtained a high answer percentage (greater or equal to $60 \%$ ) in the triangulated food test, odor identification and odor discrimination tests were also included. Therefore, 15 participants (4 men and 11 women) integrated the panel.

Then, the panelists evaluated raw ovine meat during the training sessions. The test consisted of generating and selecting descriptive terms over two sessions. Afterwards, panelists defined and selected the intensity of attributes using a 9-point numeric scale, on which 1 signified the minimum intensity perception and 9 signified the maximum over four sessions (Table 1; ISO 13299-2016). The panelists were trained over ten sessions with a scheduled between 10 a.m. and 2 p.m until the group variation coefficient (VC) was $30 \%$. The panelists were ready to assess the samples of longissimus muscles for appearance, odor and texture parameters indicated in table 1 (Stone et al., 1974; Civille \& Liska, 1975; Martínez-Arellano et al., 2013). Trained panelists evaluated three raw samples after $15 \mathrm{~min}$ blooming period $\left(18 \pm 2{ }^{\circ} \mathrm{C}\right)$ using a randomized three-digit code (FIZZ v2.3) (Biosystemes 2007, Couternon, France), over six sessions scheduled between $10 \mathrm{a} . \mathrm{m}$. and $2 \mathrm{p} . \mathrm{m}$. The samples were placed in porcelain dishes.

\subsection{Physicochemical analysis}

Warner-Bratzler shear force (WBSF) was evaluated and texture profile analysis (TPA) was performed on raw meat using a texture analyzer (TA-XT2Plus and the Texture Exponent 32, 2009 software; Texture Technology Corp., New York, NY, USA). The WBSF used the following parameters: sample size, $1 \mathrm{~cm}^{3}$; room temperature $18 \pm 2{ }^{\circ} \mathrm{C}$; the steel blade perpendicular to the fiber; test speed, $1 \mathrm{~mm} \cdot \mathrm{s}^{-1}$; and down stroke distance, $30 \mathrm{~mm}$. For TPA, the following parameters were used: $1 \mathrm{~cm}^{3}$ sample size; cylindrical $50 \mathrm{~mm}$ diameter probe of ebonite PMS $/ 50$; compression, $30 \%$; test speed, $1 \mathrm{~mm} \cdot \mathrm{s}^{-1}$; room temperature $18 \pm 2{ }^{\circ} \mathrm{C}$. Determinations were carried out in quadruplicate.

Acidic protease activity was evaluated by using $1 \%$ $(\mathrm{w} / \mathrm{v})$ hemoglobin as the substrate in universal buffer, pH 3 (Dublán-García et al., 2006), and neutral protease activity was evaluated by using $1 \%(\mathrm{w} / \mathrm{v})$ casein as the substrate in $20 \mathrm{mM} \cdot \mathrm{l}^{-1}$ phosphate buffer, $\mathrm{pH} 7$, containing $0.9 \%(\mathrm{w} / \mathrm{v}) \mathrm{NaCl}$ (Yamaguchi et al., 1982).

\subsection{Two-dimensional (2D) electrophoresis of myofibrillar proteins}

Sample preparation. Raw meat $(1 \mathrm{~g})$ was homogenized with $8 \mathrm{~mL}$ of $20 \mathrm{mM}$ Tris- $\mathrm{HCl}$ buffer, $\mathrm{pH} 7.6$, containing $2 \mathrm{mM}$ EDTA, $4 \mathrm{mM} \mathrm{MgCl}, 0.2 \mathrm{mM}$ PMSF, and $0.2 \mathrm{mM}$ trypsin inhibitor (Begonya et al., 2010). The sample was then pelleted, rinsed five times in the above-described buffer, and solubilized in $7 \mathrm{M}$ urea, $2 \mathrm{M}$ thiourea, 2\% CHAPS, and 1\% DTT. Samples for 2D electrophoresis and western blotting (WB) were collected at days 3,5 , and 14 post mortem. The protein concentration of each sample was determined in triplicate using a modified Bradford assay (Bio-Rad Protein Assay; Bio-Rad, Richmond, CA, USA).

2D electrophoresis. IPG 3-10 strips (Ready Strip $^{\text {TM }}$ IPG Strips, Bio-Rad) were used for the 2D electrophoresis of myofibrillar proteins. The protein sample was solubilized to $0.5 \mu \mathrm{g} \cdot \mu \mathrm{L}^{-1}$ in rehydration buffer (8 M urea, $2 \mathrm{M}$ thiourea, 2\% CHAPS, $50 \mathrm{mM}$ DTT, $1.5 \mu \mathrm{l}$ ampholite, $\mathrm{pH}$ 3-10 [100X, Bio-Rad], $0.002 \%$ bromophenol blue). Each IPG strip was passively rehydrated with the before mentioned solution for $23 \mathrm{~h}$ at $20^{\circ} \mathrm{C}$, and isoelectric focusing (the first dimension of electrophoresis) was run on a Protean ${ }^{\circledR}$ IEF Cell (Bio-Rad). The IPG strip was

Table 1. Descriptive attributes, scale, definition and technique in raw meat - Descripteurs, échelle, définition et technique de la viande crue.

\begin{tabular}{|c|c|c|c|}
\hline Attribute & Scale & Definition & Technique \\
\hline Moisture & Dry to succulent & $\begin{array}{l}\text { Surface textural attribute which } \\
\text { describes the perception of water } \\
\text { absorbed by or released from meat }\end{array}$ & $\begin{array}{l}\text { References were presented in a } \\
\text { PowerPoint } \subset \text { slide presentation along } \\
\text { with the attributes of images and their } \\
\text { numeric scale }\end{array}$ \\
\hline Bloody odor & $\begin{array}{l}\text { Barely perceivable } \\
\text { to strong }\end{array}$ & Quantification of ovine blood odor & $\begin{array}{l}\text { Smell the meat at } 2 \mathrm{~cm} \text { from the nose } \\
\text { for } 5 \mathrm{~s}\end{array}$ \\
\hline Greasy odor & $\begin{array}{l}\text { Barely perceivable } \\
\text { to strong }\end{array}$ & $\begin{array}{l}\text { Quantification of typical ovine fat } \\
\text { odor }\end{array}$ & $\begin{array}{l}\text { Smell the meat at } 2 \mathrm{~cm} \text { from the nose } \\
\text { for } 5 \mathrm{~s}\end{array}$ \\
\hline Manual tenderness & Soft to hard & $\begin{array}{l}\text { Mechanical textural attribute relating } \\
\text { to the force necessary to give a } \\
\text { deformation or penetration in meat }\end{array}$ & $\begin{array}{l}\text { Press the lean meat portion by index } \\
\text { finger }\end{array}$ \\
\hline
\end{tabular}


incubated with $800 \mu \mathrm{l}$ of buffer containing $6 \mathrm{M}$ urea, $0.375 \mathrm{M}$ Tris- $\mathrm{HCl}, \mathrm{pH} 8.8,2 \%$ SDS, and $50 \mathrm{mM}$ DTT, followed by incubation in the same solution containing $150 \mathrm{mM}$ of iodoacetamide instead of DTT. For the second dimension of electrophoresis, the IPG strip was incubated for $15 \mathrm{~min}$ in a test tube containing running buffer, pH 8.3 (Laemmli, 1970), and SDS-PAGE was carried out on $12 \% \mathrm{~T}$ gels using a Mini Protean III system (Bio-Rad) at $150 \mathrm{~V}$ and $18 \pm 1{ }^{\circ} \mathrm{C}$. Broad-range molecular weight markers were used (205-6.5 kDa; Sigma). The gels were stained with $0.5 \%$ potassium and aluminum sulfate, $10 \%$ absolute ethanol, $0.022 \%$ Coomassie blue G-250, and 5.5\% orthophosphoric acid, and images were digitalized with a Gel-Doc ${ }^{\mathrm{TM}}$ XR (Molecular Imager, Imaging Systems; Bio-Rad).

\subsection{Western blotting of myofibrillar proteins}

Resolved proteins were transferred to a membrane (Sequi-Blot PVDF, $0.2 \mu \mathrm{m}$; Bio-Rad) in transfer buffer, pH 8.3 (25 mM Tris, $192 \mathrm{mM}$ glycine, $0.05 \%$ SDS, $20 \%$ methanol), for $12 \mathrm{~h}$ at $30 \mathrm{~V}$ and $15^{\circ} \mathrm{C}\left(\right.$ Criterion $^{\mathrm{TM}}$ Blotter; Bio-Rad). The membranes were blocked twice in 5\% non-fat milk dissolved in TBST (pH 7.5, $150 \mathrm{mM}$ $\mathrm{NaCl}, 20 \mathrm{mM}$ Tris-HCl, 0.1\% Tween-20) for $30 \mathrm{~min}$ each time, and then rinsed three times in TBST for $5 \mathrm{~min}$ each time. Each blocked membrane was incubated for $1.5 \mathrm{~h}$ at $37^{\circ} \mathrm{C}$ with monoclonal anti-desmin (DE-U-10; Sigma Aldrich) diluted 1:200 in TBST containing 0.5\% non-fat milk. The membranes were washed for $10 \mathrm{~min}$ with TBST containing $0.5 \%$ non-fat milk, rinsed twice with TBST for 5 min each time, and incubated with IgG-HRP sc-2005 anti-goat (1:10,000; Santa Cruz Biotechnology, Dallas, TX, USA), monoclonal antivinculin (1:1,000, MAB3574; Millipore, Billerica,
MA, USA), or monoclonal anti-myosin (1:200, MY-32; Sigma Aldrich) for $1 \mathrm{~h}$ at $20^{\circ} \mathrm{C}$. Following incubation with the appropriate secondary antibody, the membranes were rinsed with TBST for $10 \mathrm{~min}$ and then with TBS (pH 7.5, $150 \mathrm{mM} \mathrm{NaCl}, 20 \mathrm{mM}$ Tris- $\mathrm{HCl}$ ) for $5 \mathrm{~min}$. The protein spots were visualized using an Immobilon Western Chemiluminescent HRP kit (Millipore) with incubation for $10 \mathrm{~min}$, and exposed to film (Logic 1500 Kodak; Imaging System).

\subsection{Statistical analysis}

The relative protein concentrations obtained by western blot analysis and their relationships with the physicochemical and sensory parameters of raw and grilled lamb meat were analyzed by multiple factorial analysis using the XLSTAT software 2012, Addinsoft, v10.0, New York, USA.

\section{RESULTS}

\subsection{Analysis of sensory and physicochemical parameters}

Results for sensory and physicochemical parameters are presented in table 2, showing that moisture had the maximum value on day 14 as well as the bloody and greasy odor muscle. Manual tenderness did not significantly differ during storage, but the texture parameters, WBSF and TPA, reached their maximum hardness values on day 3 . WBSF declined from $2.6 \mathrm{~kg}$ on day 3 to $1.9 \mathrm{~kg}$ over the following days $(p \leq 0.001)$. In addition an increment in the acidic protease activity was observed at day 3 (5.38 UI· $\mathrm{mg}^{-1}$ protein).

Table 2. Mean sensory attributes scores and physicochemical parameters for raw ovine meat during 14 days of vacuum storage in at $2{ }^{\circ} \mathrm{C}$ - Valeurs moyennes des propriétés sensorielles et des paramètres physico-chimiques de la viande ovine pendant 14 jours de stockage sous vide à $2{ }^{\circ} \mathrm{C}$.

\begin{tabular}{|c|c|c|c|c|}
\hline Attribute & Acronym & Day 3 & Day 5 & Day 14 \\
\hline Moisture & $\mathrm{MO}$ & $5.6 \pm 0.3^{b}$ & $5.8 \pm 0.8^{\mathrm{ab}}$ & $6.0 \pm 0.8^{\mathrm{a}}$ \\
\hline Bloody odor & $\mathrm{BO}$ & $2.6 \pm 0.6^{\mathrm{b}}$ & $2.8 \pm 0.6^{\mathrm{b}}$ & $3.1 \pm 0.7^{\mathrm{a}}$ \\
\hline Greasy odor & GO & $1.6 \pm 0.3^{\mathrm{b}}$ & $1.7 \pm 0.3^{\mathrm{ab}}$ & $1.8 \pm 0.4^{\mathrm{a}}$ \\
\hline Manual tenderness & MT & $4.3 \pm 0.8^{\mathrm{a}}$ & $4.3 \pm 0.7^{\mathrm{a}}$ & $4.4 \pm 0.7^{\mathrm{a}}$ \\
\hline Warner Bratzler shear-force & WBSF (kg) & $2.6 \pm 0.9^{a}$ & $1.9 \pm 0.5^{\mathrm{b}}$ & $1.9 \pm 0.6^{\mathrm{b}}$ \\
\hline Hardness-TPA & $\mathrm{HA}(\mathrm{kg})$ & $0.29 \pm 0.58^{\mathrm{a}}$ & $0.17 \pm 0.18^{\mathrm{b}}$ & $0.17 \pm 0.17^{\mathrm{b}}$ \\
\hline Acid protease & APr (UI mg protein $\left.{ }^{-1}\right)$ & $5.38 \pm 0.58^{\mathrm{a}}$ & $4.80 \pm 1.34^{\mathrm{b}}$ & $4.23 \pm 0.89^{b}$ \\
\hline Neutral protease & NPr (UI mg protein $\left.{ }^{-1}\right)$ & $1.90 \pm 0.50^{\mathrm{b}}$ & $3.60 \pm 1.21^{\mathrm{a}}$ & $1.29 \pm 0.48^{c}$ \\
\hline
\end{tabular}

Means within a row with the same subscript (days 3, 5, and 14) are not significantly different $(p<0.05)$, as assessed by Fisher's least significant difference test - les moyennes dans une même rangée avec la même minuscule (jours 3, 5 et 14) ne sont pas significativement différentes $(\mathrm{p}<0,05)$ selon le test de Fischer. 


\subsection{D electrophoresis and blotting of myofibrillar proteins}

Figure 1 shows the electrophoresis and blotting of myofibrillar proteins, where a signal corresponding to intact desmin (Figure 1a) was highly intense on day 3, while those of its degradation products (three spots) were first seen on day 14. The relative concentration of intact desmin decreased to $20-40 \%$ of the day 3 level by day 5 , and from there on to $16 \%$ of the initial level on day 14 . In addition, the relative expression level for vinculin, compared to the level seen on day 3 , decreased to $38 \%$ and $24 \%$ on days 5 and 14, respectively (Figure 1b). Finally, myosin heavy chain (MHC) was observed as one spot on day 3 and two spots thereafter. On day 14, the relative protein concentrations of the spots were reduced to $3 \%$ and 9\%, respectively, on day 5 (Figure 1c).

\subsection{Multiple factor analysis}

Multiple factor analysis was used to correlate the relative protein concentrations (desmin, vinculin, myosin), physicochemical parameters (protease activity, WBSF, hardness-TPA), and sensory parameters (manual tenderness). Three groups of variables were used: the protein variables included the relative protein concentrations for desmin, vinculin, and myosin; the physicochemical variables included protease activity, WBSF, and hardness-TPA; and the sensory variable consisted of manual tenderness. The first axis explained $58.53 \%$ and the second $47.47 \%$ of total variance (Figure 2). The $R v$ coefficients were generated and considered significant as values where higher than 0.6, according to Cartier et al. (2006). The $R v$ values were 0.6 and 0.88 , respectively, for the protein-sensory parameters and protein-physicochemical parameters, while that for the physicochemical-sensory parameters was 0.6.
Figure 2 shows that the physicochemical parameters were followed by the protein parameters described on day 3 in the first dimension, whereas this order was reversed on day 5. Finally, day 14 was described by the protein parameters, followed by the sensory and then physicochemical parameters. As shown in figure 2 , the sensory parameters were overall less descriptive than the other parameters. While, figure 3 shows a correlation circle comparing the protein, physicochemical and sensory parameters. The vectors showed that WBSF was correlated with the relative desmin concentration on day 3 concentration

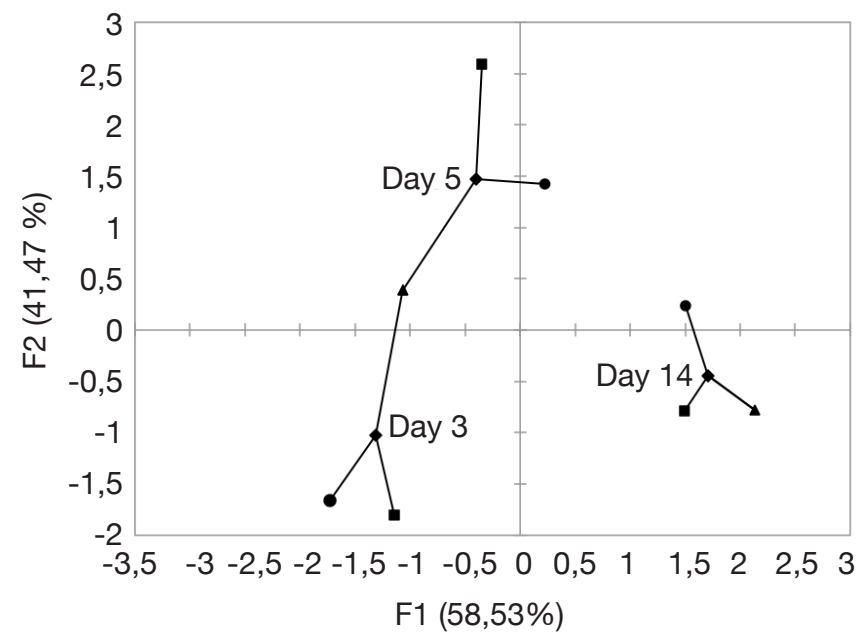

Figure 2. Multiple Factorial Analysis (MFA) of individual products plotted for raw ovine meat on days 3, 5, and 14 of storage $(\boldsymbol{\nabla})$ with respect to sensory parameters $(\boldsymbol{\Delta})$, physicochemical parameters (O), and relative levels of selected proteins (ם) - Analyse factorielle multiple (AFM) de produits individuels tracés pour la viande ovine à 3, 5 et 14 jours de stockage $(\diamond)$, en fonction des paramètres sensoriels ( $\mathbf{\Delta})$, des paramètres physico-chimiques $(\mathbf{O})$ et de la quantité relative des protéines sélectionnées ( $\mathbf{\square})$.

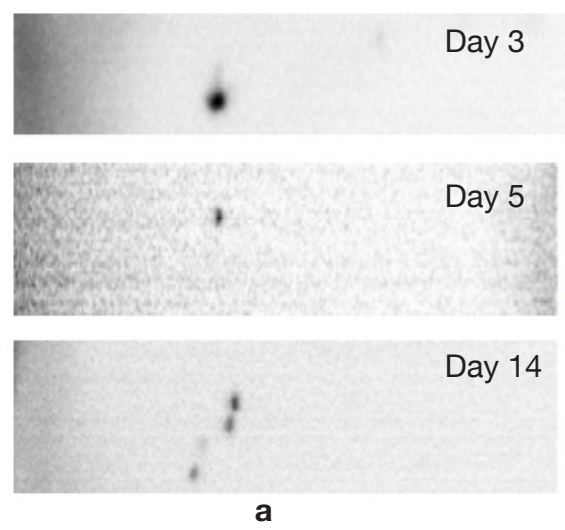

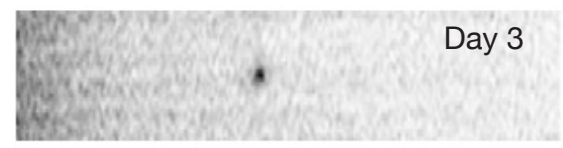
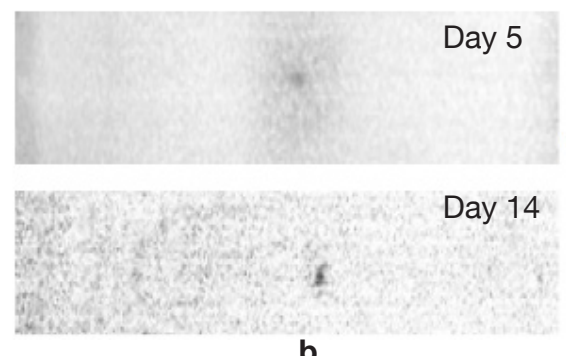

b
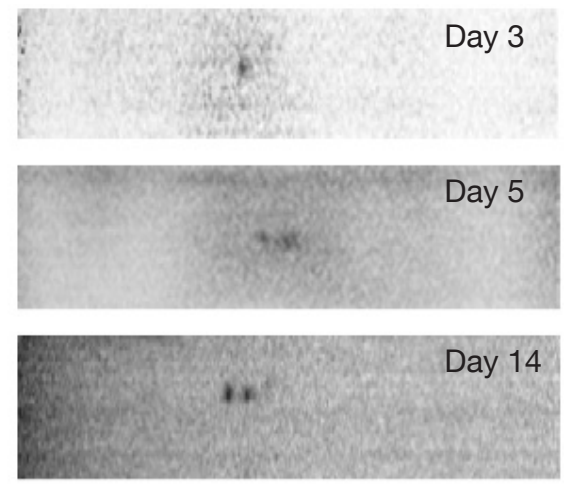

C

Figure 1. Western blotting of desmin (a), vinculin (b) and myosin (c) in ovine meat on days 3, 5, and 14 of storage - Images de western blot de la desmine (a), de la vinculine (b) et de la myosine (c) présentes dans la viande ovine après 3, 5 et 14 jours de stockage. 


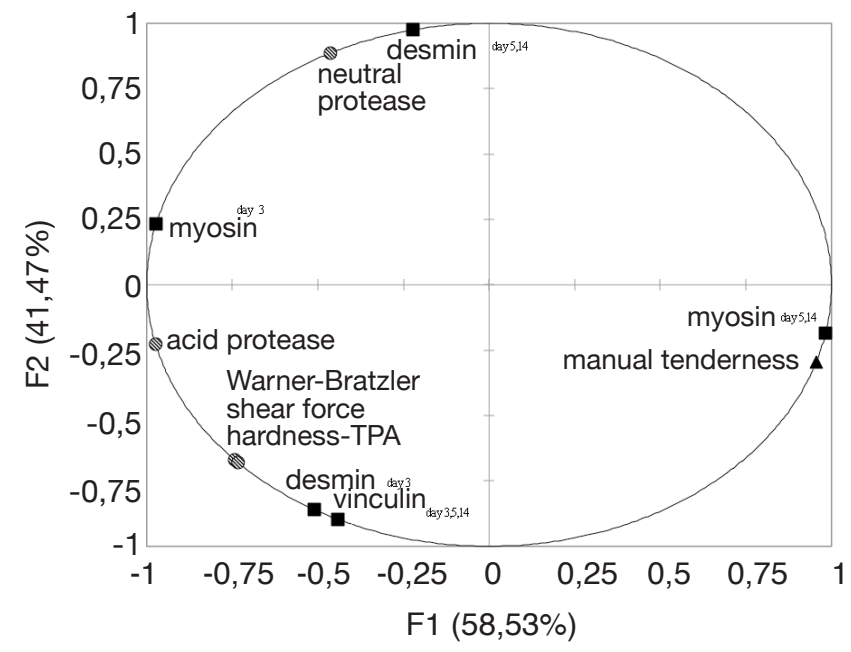

Figure 3. MFA variable correlation circle obtained from analysis of sensory parameters ( $\mathbf{\Delta})$, physicochemical parameters ( $\mathbb{Q}$ ), and the levels of selected proteins ( $\mathbf{\square})$ in ovine meat during 14 days of storage - Cercle des corrélations de l'AFM obtenu à partir de notre analyse des paramètres sensoriels $(\mathbf{\Delta})$, des paramètres physicochimiques $(\mathbb{Q})$ et de la quantité des protéines sélectionnées (ם) dans la viande ovine pendant 14 jours de stockage.

$(r=0.95)$. In addition, the shear force was correlated with the relative vinculin concentrations on days 3 , 5 and $14(\mathrm{r}=0.93)$, hardness-TPA $(\mathrm{r}=1)$, and acidic protease activity $(\mathrm{r}=0.875)$. Manual tenderness was positively correlated with myosin on days 5 and $14(\mathrm{r}=$ 0.9 ), and myosin on day 3 was positively correlated with the neutral $(r=0.65)$ and acidic $(r=0.89)$ activities. But the relative myosin concentration on day 3 was negatively correlated with manual tenderness $(r=-0.98)$, and the relative myosin concentrations on days 5 and 14 were negatively related to acidic protease activity $(\mathrm{r}=-0.91)$.

\section{DISCUSSION}

\subsection{Analysis of sensory and physicochemical parameters}

Among the sensory parameters, the increase in moisture and variation in odor may be related to protein denaturation and the release of water to the meat surface, which reflects more light. Similarly, Kosowska et al. (2017) reported that non-ripened beef had a weak, plain aroma, whereas the ripening process increased and intensified its flavor; for example, the ripening for up to 14 days increased the greasy taste. Those changes may be related to the presence of reactive compounds (acids, alcohol, aldehydes or ketones) originated by transformation in fatty tissue (phospholipid). On the other side, some authors have proposed that neutral proteases are the main factors responsible for enzymatic activity in meat, while others have suggested that there is a multi-enzymatic process involving neutral proteases, acid proteases, proteasomes and caspases that may explain the results associated to texture (Herrera-Mendez et al., 2006).

\subsection{D electrophoresis and blotting of myofibrillar proteins}

As the texture of meat is also an important attribute for the consumer, the hydrolysis levels of desmin, myosin and vinculin proteins by endogenous proteases were tested. As shown in figure 1, variations in desmin, vinculin and myosin were evident during the study. These findings are consistent with other authors, for instance Kristensen \& Purslow (2001), who reported that desmin immune-labeling declined to $29 \%$ of the initial value in pork by day 10 of storage, and Iwanowska et al. (2010), who observed a gradual diminution of the relative desmin concentration over time in bull's meat, with degradation products increased on days 2 and 4 of storage. While, vinculin reduction was also reported by Kristensen \& Purslow (2001) showing that the relative vinculin concentration in pork decreased in $37 \%$ of its initial value after 10 days of storage. In relation to myosin, a study from Lametsch et al. (2003) indicated that only the globular portion of myosin is reduced during the first $48 \mathrm{~h}$ post mortem in pork, and that the resulting degradation products were correlated with meat tenderness. However, other authors observed that neither myosin nor actin were broken down post mortem in bovines (Huff-Lonergan et al., 1996).

\subsection{Multiple factor analysis}

Multiple factor analysis was used to correlate the relative protein concentrations, physicochemical parameters and sensory parameters. This technique analyzes the similarity among groups of observations explained by different sets of variables with comparable or opposing scales; the influence of each variable is balanced, multiple groups of data are compared, and per-attribute correlation patterns are generated (Abdi \& Valentin, 2007). Significant $R v$ coefficients with 0.6 value were observed for the protein-sensory parameters and protein-physicochemical parameters. These findings agree with those of Muroya et al. (2010), who reported that some cytoskeletal proteins, including troponin- $T$ and desmin, are related to meat quality characteristics of pork. Wheeler \& Koohmaraie (1999) found that desmin is a good indicator of post mortem proteolysis and tenderness in lamb. Hwang et al. (2005) reported that the labeling density of desmin in pork decreased to $46 \%$ of the initial value, but its relationship with 
WBSF was weak $(r=0.46)$. The latter finding likely reflects the inherent limitation of proteomic analysis, wherein proteins and/or their intermediary degradation products may co-migrate. Finally, actin and myosin being the most abundant proteins in meat, and their post mortem degradation affects the meat structure yielding a softer meat texture. As reported by other authors (D'Alessandro et al., 2012), there is no universal protein marker for meat, but markers need to be selected by the type of meat.

\section{CONCLUSIONS}

Ovine meat had the highest value of moisture, greasy and blood odor and the lowest value of WBSF hardness, neutral and acid protease activities on day 14. Manual tenderness was not significantly affected during storage. The relative levels of immunoblotted desmin, myosin and vinculin had correlation coefficients $(R v)$ with the physicochemical and sensory parameters greater than 0.6 , indicating that these proteins could be potential markers for predicting the texture quality of ovine meat. In the future, an electronic sensor (microarray technology), capable of testing an array of specific proteins, might be used to quickly analyze and classify carcasses on the line during the slaughter process. In addition, sarcoplasmic proteome could be studied (triosephosphate isomerase, HSP20, etc.) to be linked with sensory and physicochemical parameters.

\section{Bibliography}

Abdi H. \& Valentin D., 2007. Multiple correspondence analysis. In: Salkind N.J., ed. Encyclopedia of measurement and statistics. Thousand Oaks, CA, USA: SAGE Publications Inc., 651-657.

Anderson M.J., Lonergan S.M. \& Huff-Lonergan E., 2012. Myosin light chain 1 release from myofibrillar fraction during post mortem aging is a potential indicator of proteolysis and tenderness of beef. Meat Sci., 90, 345351, doi.org/10.1016/j.meatsci.2011.07.021

ASTM, 1981. Guidelines for the selection and training of sensory panel members, STP758. West Conshohocken, PA, USA: ASTM International, 1-12, doi.org/10.1520/ stp41626s

Begonya M., Kerry J.P. \& Mullen A.M., 2010. High pressure induced changes on sarcoplasmic protein fraction and quality indicators. Meat Sci., 85, 115-120, doi.org/10.1016/j.meatsci.2009.12.014

Cartier R. et al., 2006. Sorting procedures as an alternative to quantitative descriptive analysis to obtain a product sensory map. Food Qual. Preference, 17(7), 562-571, doi.org/10.1016/j.foodqual.2006.03.020

Civille G.V. \& Liska I.H., 1975. Modifications and applications to foods of the general foods sensory texture profile technique. J. Texture Stud., 6, 19-31, doi. org/10.1111/j.1745-4603.1975.tb01115.x

D'Alessandro A. et al., 2012. Love me tender: an omics window on the bovine meat tenderness network. J. Proteomics, 75, 4360-4380, doi.org/10.1016/j. jprot.2012.02.013

Dublán-García O., Cruz-Camarillo R., GuerreroLegarreta I. \& Ponce-Alquicira E., 2006. Effect of refrigerated storage on proteolytic activity and physicochemical and microstructural properties of giant squid mantle muscle. J. Muscle Foods, 17, 291310, doi.org/10.1111/j.1745-4573.2006.00051.x

FAO, 2019. Meat market review, March. Roma: FAO.

Gagaoua M. et al., 2017. Associations among protein biomarkers and $\mathrm{pH}$ and color traits in longissimus thoracis and rectus abdominis muscles in protected designation of origin Maine-Anjou cull cows. J. Agric. Food Chem., 65, 3569-3580, doi.org/10.1021/acs. jafc.7b00434.s001

Herrera-Mendez C.H., Becila S., Boudjellal A. \& Ouali A., 2006. Meat aging: reconsideration of the current concept. Trends Food Sci. Technol., 17, 394-405, doi. org/10.1016/j.tifs.2006.01.011

Huff-Lonergan E. et al., 1996. Proteolysis of specific muscle structural proteins by mu-calpain at low $\mathrm{pH}$ and temperature is similar to degradation in post mortem bovine muscle. J. Anim. Sci., 74, 993-1008, doi. org/10.2527/1996.745993x

Hwang I.H. et al., 2005. Assessment of post mortem proteolysis by gel-based proteome analysis and its relationship to meat quality traits in pig longissimus. Meat Sci., 69, 79-91, doi.org/10.1016/j. meatsci.2004.06.019

ISO 13299, 2016. Sensory analysis: methodology - general guidance for establishing a sensory profile. Geneva, Switzerland: ISO.

Iwanowska A. et al., 2010. Changes in proteins and tenderness of meat from young bulls of four breeds at three ages over 10 days of cold storage. Anim. Sci. Papers Rep., 28(1), 13-25.

Jandasek J., Milerski M. \& Lichovnikova M., 2014. Effect of sire breed on physico-chemical and sensory characteristics of lamb meat. Meat Sci., 96(1), 88-93, doi.org/10.1016/j.meatsci.2013.06.011

Kiran M. et al., 2016. Understanding tenderness variability and ageing changes in buffalo meat: biochemical, ultrastructural and proteome characterization. Animal, 10(6), 1007-1015, doi.org/10.1017/ s1751731115002931

Kosowska M.A., Majcher M. \& Fortuna T., 2017. Volatile compounds in meat and meat products. Food Sci. Technol., 37(1), 1-7, doi.org/10.1590/1678-457x .08416

Kristensen L. \& Purslow P., 2001. The effect of ageing on the water-holding capacity of pork: role of cytoskeletal proteins. Meat Sci., 58(1), 17-23, doi.org/10.1016/ s0309-1740(00)00125-x 
Laemmli U.K., 1970. Cleavage of structural proteins during the assembly of the head of bacteriophage $t 4$. Nature, 227, 680-685, doi.org/10.1038/227680a0

Lametsch R. et al., 2003. Post mortem proteome changes of porcine muscle related to tenderness. J. Agric. Food Chem., 51(24), 6992-6997.

Martínez-Arellano I., Severiano-Pérez P., Fernández F. J. \& Ponce-Alquicira E., 2013. Changes in the physicochemical and sensory characteristics in raw and grilled ovine meat. J. Sci. Food Agric., 93, 1743-1750, doi.org/10.1002/jsfa.5964

Muela E. et al., 2012. Effect of freezing method and frozen storage duration on lamb sensory quality. Meat Sci., 90, 209-215, doi.org/10.1016/j.meatsci.2011.07.003

Muroya S., Ertbjerg P., Pomponio L. \& Christensen M., 2010. Desmin and troponin T are degraded faster in type IIb muscle fibers than in type I fibers during post mortem aging of porcine muscle. Meat Sci., 86(3), 764-769, doi. org/10.1016/j.meatsci.2010.06.019

OECD, 2020. Meat consumption (indicator), doi. org/10.1787/fa290fd0-en

Picard B. et al., 2014. Inverse relationships between biomarkers and beef tenderness according to contractile and metabolic properties of the muscle. J. Agric. Food Chem., 62, 9808-9818, doi.org/10.1021/jf501528s

Pospiech E. et al., 2007. Proteins of meat as a potential indicator of its quality-a review. Pol. J. Food Nutr. Sci., 57(1), 11-16.

Revilla I. et al., 2009. Comparison of the sensory characteristics of suckling lamb meat: organic against conventional production. Czech J. Food Sci., 27, 267270, doi.org/10.17221/949-cjfs
Severiano-Pérez P.,Cadena-Aguilar A.A., Vargas-Chanes D. \& Guevara-Guzmán R., 2012. Questionnaire on Mexicans' familiarity with odor names. J. Sensory Stud., 27, 277-285, doi.org/10.1111/j.1745-459x.2012.00390.x

Starkey C.P. et al., 2016. Do sarcomere length, collagen content, $\mathrm{pH}$, intramuscular fat and desmin degradation explain variation in the tenderness of three ovine muscles? Meat Sci., 113, 51-58, doi.org/10.1016/j. meatsci.2015.11.013

Stone H. et al., 1974. Sensory evaluation by quantitative descriptive analysis. Food Technol., 28, 24-33.

Tomisaka Y. et al., 2010. Changes in water-holding capacity and textural properties of chicken gizzard stored at $4{ }^{\circ}$ C. J. Anim. Sci., 81, 362-368, doi.org/10.1111/j.17400929.2010.00739.x

Wheeler T.L. \& Koohmaraie M., 1999. The extent of proteolysis is independent of sarcomere length in lamb longissimus and psoas major. J. Anim. Sci., 77, 24442451, doi.org/10.2527/1999.7792444x

Wheeler T.L., Shackelford S.D. \& Koohmaraie M., 2000. Variation in proteolysis sarcomere length, collagen contentand tendernessamongmajorporkmuscles.J.Anim. Sci., 78(4), 958-965, doi.org/10.2527/2000.784958x

Yamaguchi T., Yashita Y., Takeda I. \& Kiso H., 1982. Proteolytic enzymes in green asparagus, kiwi fruit and miut: occurrence and partial characterization. Agric. Biol. Chem., 46(8), 1983-1986.

(35 ref.) 